\title{
MORALITY AND LAW: \\ Critics upon H.L.A Hart's Moral Paradigm Epistemology Basis based on Prophetic Paradigm ${ }^{\Omega}$
}

\author{
Khudzaifah Dimyati, Absori, Kelik Wardiono \\ Doctoral Program of Law Universitas Muhammadiyah Surakarta \\ E-mail:kd255@ums.ac.id \\ and \\ Fitrah Hamdani \\ Faculty of Law, Institut Ilmu Sosial dan Budaya Sumbawa
}

\begin{abstract}
The research focuses on a critism study of epistemologycal basis of the relation between law and morality in H.L.A. Hart's rational paradigm. It is according to prophetic paradigm which is based on philosophical approach. According to the analysis, it is concluded that Hart's opinion is based on the epistemological basic assumptions including the primary and secondary rules; Value/Ethics including epistemological ethics such as autonomous, individual, procedural, and relative ethics while the pro-phetic paradigm is based on the epistemological assumptions in which Relative Morailty is the result of creation and will of absolute reality. Meanwhile, Norm of morality means the reality should be cre-ated by the competent will through a delegate with epistemological ethics such as the combination between reality of society and apocalyptical values.
\end{abstract}

Keywords: moral concepts, prophetic paradigm and rational paradigm

Abstrak

Penelitian yang menfokuskan kajian tentang kritik terhadap basis epistemologi tentang relasi antara hukum dan moral dalam paradigma rasional dari H.L.A, berdasarkan paradigma profetik yang mendasarkan pada metode pendekatan filosofis. Berdasarkan kajian yang dilakukan disimpulkan, bahwa pendapat dari H.LA, Hart mendasarkan pada asumsi-asumsi dasar epistemologi, yang meliputi aturan primer (primary rules); dan aturan sekunder(secundary rules); sedang Nilai/Etos, meliputi: etos epistemologi, yang berupa: otonom, individual, prosedural dan relatif, sedangkan paradigma profetik mendasarkan pada Asumsi Epistemologi, yaitu Moralitas relatif merupakan hasil penciptaan dan kehendak realitas absolut dan Norma moralitas, yaitu realitas seharusnya (sollen) yang diciptakan atas kehendak yang berwenang melalui utusan, dengan nilai/etos epistemologi berupa perpaduan antara realitas masyarakat dan nilai-nilai kewahyuan.

Kata Kunci: konsep moral, paradigma profetik, dan paradigma rasional

\section{Introduction}

Paradigm is a set of basic belief system or metaphysics related to the main principles. A paradigm, to its believers, will represent a worldview which defines world nature (reality), one's place or position in it and the probability of distance between the world (reality) and its parts. In short, it can be concluded that paradigm is a basic system belief which relies on ontology, epistemology and methodology assumptions. Ontology assumptions question about the form and nature of reality. Epistemology as- sumptions question about the relation between the researchers with the studied reality. While methodology assumptions question on how the researchers try to explain what they believe to be known. ${ }^{1}$

$\Omega$ This research is part of Hibah Kompetensi, funded by DP2M Kementerian Riset, Teknologi, dan Pendidikan Tinggi 2017.

1 Turnomo Rahardjo. "Landasan Filosofis Penelitian Komunikasi”, Jurnal Semai Komunikasi, Vol. II No. 1, December 2011, Semarang: Sekolah Tinggi Ilmu Komunikasi Semarang, page 3. 
Rational paradigm (which becomes the legal basis of positivistic philosophical schools) in philosophy of law terminology ${ }^{2}$ with basic thesis that science is the only scientific knowledge. Then, positivism demands that philosophy needs to have methods similar to science. The main task of philosophy, according to positivism, is to find general principle to every science and is henceforth used as a guidance for human behavior as well as the basis for social organization. Therefore, positivism denies all forms of scientific responsibilities which exceed the limits of empirical facts and the law asserted by science. $^{3}$

Law positivism focuses on formality based on real project and departs from deduction with logic at the place significant to the study of law. Law can be seen as an autonomous and pure institution; therefore, in order to have legitimate power and applicable and it cannot and shall not be interfered with non-legal aspects such as politics, economics, socials even morality. Liberalism law theory highly defends one's freedom; thus, protection of individual law is important to bring out the rule of law. ${ }^{4}$

In the next development, positivism proposed by Comte and Spencer had then become inspiration to the upcoming course of juridical-

2 See Inge Dwisvimiar, "Keadilan Dalam Perspektif Filsafat Ilmu Hukum”, Jurnal Dinamika Hukum, Vol. 11 No. 3, September 2011, Purwokerto: Faculty of Law Universitas Jenderal Soedirman, page 506.

3 Noor Azizah. "Urgensi Filsafat Ilmu Bagi Ilmu Hukum", Jurnal Al 'Ulum, Vol. 51 No. 1, January 2012, Gorontalo: IAIN Sultan Amai, page 54; See also similar issue on D.H.M. Meuwissen, "Pengembangan Hukum", Jurnal Hukum Pro Justitia, Year XII No. 1, January 1994, Bandung: Faculty of Law Universitas Parahyangan; D.H.M. Meuwissen, "Teori Hukum", Jurnal Hukum Pro Justitia, Year XII No. 1, April 1994, Bandung: Faculty of Law Universitas Parahyangan; D.H.M. Meuwissen, "Filsafat Hukum", Jurnal Hukum Pro Justitia, Year XII No. 1, July 1994, Bandung: Faculty of Law Universitas Parahyangan; D.H.M. Meuwissen, "Ilmu Hukum", Jurnal Hukum Pro Justitia, Year XII No. 1, July 1994, Bandung: Faculty of Law Universitas Parahyangan.

Agus Raharjo, "Hukum dan Dilema Pencitraannya: Transisi Paradigmatis Ilmu Hukum dalam Teori dan Praktek", Jurnal Hukum Pro Justitia, Vol. 24. No. 1, January 2006, Bandung: Faculty of Law Universitas Parahyangan, page 14; see and compare to Agus Raharjo's, “Membangun Hukum yang Humanis", Jurnal Hukum Pro Justitia, Yea XX No. 2, April 2002, Bandung: Faculty of Law Univer sitas Parahyangan; and Satjipto Rahardjo, "Hukum Progresif: Hukum yang Membebaskan", Jurnal Hukum Progresif, Vol. 1 No. 1, April 2005, Semarang: Law Studies Doctoral Program Universitas Diponegoro. positivism. This course believed that the only law accepted as a law is the rule of law; therefore, this law can be ensured and practiced.

Law positivism course is also known as legisme course. This course juxtaposes law with Constitution; there is no law outside Constitution. The only source of law is Constitution. This positive law point of view is upheld by Paul Laband, Jellineck, Rudolf von Jherings, Hans Nawiasky, Hans Kelsen and others.

Law positivism believes that law should be viewed under the provisions of Constitutions by which the rule of law can be verified. Anything outside the Constitutions shall be excluded as law. Law should be separated from morality, even though positivists admit that the focus on legal norms is associated with moral discipline, theology, sociology and politics which affect the development of law system. Morality can be accepted inside the law system if it is recognized and legalized by the authorities who impose it as law. Hart acknowledged that authoritative norm is usually accompanied by penalties of some sorts (either social penalties or specific sanction for public authorities), these penalties have different ways instead of the usual coercion (habitual behavior), especially because the sanction is approved by the people, created and accepted by the official authorities; hence, it is legitimate. ${ }^{5}$

Hans Kelsen on his law theory, the Pure Theory of Law, provides the underlying similarity of law as H.L.A Hart tried to answer the question, "What is law?" however; it is not a question of "what is law supposed to be?" To put it clearly, Hart's perspective related to the question of "law nature" above is about how law and its liability are different and how the relation between the commands supported by threat is.

H.L.A Hart stated that there is separation between law and morality; nonetheless, the separation is not extreme because morality should be a part of law's requirement. It is caused by

5 Candace J. Groudine"Authority: H. L. A. Hart and the Problem with Legal Positivism", The Journal of Libertarian Studies, Vol. IV. No. 3, Isumrnrr 1980, New York: Department of Philosophy Columbia University, page 274. 
two factors: first, human has limitations to do good for others: and second, Law has limitation in organizing people's development.

Hart set morality as the minimum requirement of law, by overcoming the rigidity that exists in Austin's classic legal positivism in which law is considered as institution impermeable to morale. However, to some extent, Hart and Austin had come into agreement, especially related to the separation between law and morality but they reject absolute closure on morale.

According to Hart, the relation between law and morality in reality: first, law manifests moral ideas; second, morality and law have independent relationship; third, law must actualize law ideas, Fourth, moral values affect law, fifth, law, by definition its definition, embodies morale; and sixth, looking at the fact of human nature and the world they live in, morality rules have the same minimum side. ${ }^{6}$

According to Hart, Law system is social rules system. As an example, regulation is commonly considered as an excuse or justification for an action, and violations are generally open for critics. Therefore, the rule of law is normative while custom is otherwise. Hence, in other words, regulation can assert rights and authority while custom does not have power to adjust one's behavior. The validity of positive law which is dominant opposes customs in subordinate area. ${ }^{7}$

A strong border line between "basis/ source and ethics" of Western science originated in mind (ratio/aql) and Islamic science which came from God (Allah SWT) in form of 'revelation' of transcendental structure and mind (ratio/aql). Ethics of both science sources are different. Western science ethic is humanism while Islamic science ethic is humanismtheocentric. The characteristics of Western science are secular and autonomous while Islamic

\footnotetext{
6 Salman Luthan, "Dialektika Hukum dan Moral dalam Perspektif Filsafat Hukum", Jurnal Hukum IUS QUIA IUSTUM, Vol. 19 No. 4, Oktober 2012, Yogyakarta: Faculty of Law Universitas Islam Indonesia, pages 516-517.

7 Robert Summers, "Professor H.L.A. Hart Concept of Law", Duke Law Journal, Vol. 1963 No. 629, Durham: Duke University School of Law, page 631.
}

science is integralistic. It is prophetic ideals derived from Islam historical mission written in Quran Surah Ali Imran 3: (110) stated,

"You are the best community that ever emerged for humanity: you advocate what is moral, and forbid what is immoral, and believe in God."

Categorization in Quran, on its turn, stops the dispute in Western Scientists regarding to material object of natural sciences and humanities. From Western point of view, there are two things which are contradictory to science. The first point of view stated that science is a unity; therefore, there should not be natural science and social-culture sciences. Based on this perspective, even though there are differences in material objects of each field, science should not be separated into two. ${ }^{8}$

Thus, the formulation of Prophetic law in law studies, either paradigmatic, assumptions, principles, theory, methodology, or normative structures existed within are created based on Islamic epistemology basis originated from Quran and Hadiths. Through transformation process and Islamic objectification which is originated from Quran and Hadiths, the basic assumption will be built, which then eventually will become theory, doctrine, principles, rules and legal norm applied among the people is adjusted with each context.

Based on perspective of an epistemological prophetic paradigm that refers to revelation, empirical reality, and ratio, those three knowledge sources perfectly interrelated. Therefore, revelation, reality and ratio are interrelated and inseparable because revelation without ratio would be unspeakable idea that can not be defined and understood. Likewise, if ration without revelation would be an aimless thought, consequently, the debates is aimed only to show the intellectual perspective that leads to the truth because it comes from the subjectivity thought in defining things.

\footnotetext{
8 Heddy Shri Ahimsa Putera, "Paradigma Profetik: Mungkinkah?, Perlukah?", Makalah, delivered in "Saresehan Profetik 2011" held by Magister Programs in UGM, Yogyakarta, February $10^{\text {th }} 2011$, page 35.
} 


\section{Problems}

Based on the description above, the study refers to: first, how is the relation between moral and law based on rational paradigm from H.L.A Hart?; second, how is the critic of prophetic paradigm between moral and law in rational paradigm from H.L.A Hart?

\section{Research Method}

The study applied philosophical approach which aimed to explore the rational paradigm of relation between moral and law based on basic epistemology from H.L.A Hart, supported by the references of legal positivism philosophy and to criticize it through prophetic paradigm. The primary source in terms of H.L.A Hart's writings were collected from some references. The selected data were then analyzed by descriptive, interpretative and hermeneutic, and heuristic analysis.

\section{Discussion}

\section{H.L.A. Hart's Morality Concept on Rational Paradigm}

According to Hart's book, The Concept of Law, stated three issues that explain the relation between morality and law: first, how to differentiate moral ideas for justice from justice in law; second, how to differentiate moral rules from law of all social aspects and third, the various component in which law and morality interrelate.

According H.L.A Hart, justice is different from morality assesment. Justice is more specific compared to moral assessment. Justice in law concerns in two points, which are: Distribution and compensation. In term of distribution, it reveals that justice does not merely focus on person but on a group of people being treated for expanses or gains where it is distributed for them. "Hence what is typically fair or unfair is a share". ${ }^{9}$ The distributive justice in law applies: treat like case alike and treat different case different. It is applied as a proof

\footnotetext{
Margaret M. Poloma, 2000, Sosiologi Konternporer, translated from Contemporary Sociology Theory by $\mathrm{Ya}$ sogama team, Jakarta: PT. RajaGrafindo Persada, page 159.
}

that law is fair as if it all refers to assigned procedures. In compensation, justice principle applies in certain situation where some injuries happened and compensation is being claimed. In this case, law is considered fair if the compensation given corresponds to adverse consequences. ${ }^{10}$

\section{Epistemology Basic Assumption of Rational Pa- radigm based on H.L.A Hart's Concept}

The main law rule of Hart's view is social norms even though it is not always from agreement or convention. Thus, the system of law is norms that support a group of people, however, the main thought is social norm that has another normative strength through custom. It is a behavior regularities towards legal entities that take internal perspective in taking decision. It is being used by positivists as a standard to guide and evaluate their behavior and others and is being shown by their behavior. It is also used to solve the problems from social pressure to support the rules and they are ready to apply it for duties and responsibilities. Then, the particular question of positivistic is how social norms have normative strength or considered as legal norms. Positivists proposed some concepts: primary rules, and secondary rules. It is a basic assumption of ontology concepts based on the concept of Hart's law morality.

\section{The Epistemological Value/Ethics of rational paradigm based on H.L.A Hart's Concept}

According to Hart, moral assessment depends on personal assumption and determines the fairness or unfairness of law. If it is not, people is not obliged to follow the law and it is possible to sue the unfair law. For Hart, morality comes from the thought or philosophy. As a result of thought, morality is neither absolute nor universal. It is limited, unstable and it has weakness and strength etc. Moral is more about the concept of human's behavior. Moral in this case is seen as a judge in social system and is not as a subject. It is as a concept or thought of values for determining position or human's be-

10 Ibid. 
havior. Moral more refers to the assesment of the exist system values. Moral is more like a social system observation and it is relatively changing by space and time which form moral.

\section{Prophetic Paradigm Critics towards Rational Paradigm Morality Concept Based on H.L.A Hart's conception}

Prophetic Paradigm Critics towards basic assumption of Rational Paradigm Morality Concept based on Hart's conception are: first, relative moral is a result of creation and absolute reality will. Moral values and legal norms as a relative reality, are contextual subjective of moral norms that have no principles and is not identic to object. From Ghazali's view, the concepts of Masyhurat (norms and values in public space), maqbulat (norms and values in traditional belief), and Maznunat (norms and values in prediction), are not rational objective, but it is socially constructed namely an internal form that has wahimiyat (emotion) and is also influenced by external factors. ${ }^{11}$ Social belief of norms and moral values in particular society can also be traditionally constructed. However, the basic goals of emotion or God believing cannot be considered universal from inside their soul.

Based on Ghazali's perspective, the matter of norms and moral values is not absolute from God, but it should be defined by human relatively depending on situation, except qath'l, where a thought or syara' limits themselves to general or popular norms, and in ijtihad view, truth is relatively plural, which is as a result of various ijtihad from different objects.

In the context of ijtihad from relative pluralism theory, Ghazali defends autonomy principles and flexibility concept of creativity in human's life and the elasticity law; law as taklif and also mercy should be understood and defined contextually as the condition of human's life. The God's law can be enforced based on the willingness and God decision even in the form of verse, and exclude qath'l will face so-

11 Go further in Al-Ghazali, $1409 \mathrm{H} / 1988$. Mi'yar al-'/lm, ed. Sulayman Dunya, Edition. II, Egypt: al-Ma'arif, pages 193-198. me changes based on peculiar space and time with the change of zann mujtahid, while zann is subjective and contextual.

The ethics concept from Ghazali in seeing zann as an object of ijtihad can be concluded as Greek Ethics completion, as like Plato and Aristoteles, and Muslim philosopher like ibn Miskawaih, especially in seeing human reality aspect that is mono-dual and its existential function abdi and kholifah, ${ }^{12}$ or God in the earth. ${ }^{13}$ The affirmative proof can be seen on how Ghazali bravely affirmed that those four moderate coming from Greek namely Hikmah (wise), 'iffah (humble), and adalah (fair); that considered as the main of moral values and the kindness of soul that is "right way" (al-sirat al-mustaqim) that is written in Quran as the one and only guide for human and as the fundamental (usul al-din). ${ }^{14}$

Second, morality is a supposed reality (sollen) which forms the authorities will through representative. Regarding to moral causality, someone with all his action "widely" considered as God action. Since someone's action originally comes from a knowledge which brings out iradah (motive). Iradah will move qudrah (ability) that forces a physical movement. This systematic process happens compulsively (mechanical deterministic), as God jabr (force) convenient with his causality. It means someone does what he/she wants either intentionally or not. Thus, masyi'ah (will) extensively does not come from human. If it is so, it will trigger another will until formed 'an endless chain'. In consequence, Ghazali classified three (3) human actions, they are: ${ }^{18}$ Fi'il Tabi'i (natural-mechanic action), such as some people who stand barefooted; Fi'il

12 Go further in Agus Iswanto, "Relasi manusia Dengan Lingkungan dalam Al-Quran: Upaya Membangun EcoTheology", Jurnal Suhuf, Vol. 6 No. 1, 2013, Jakarta: Agency of Research, Development, Education and Training of Ministry of Religious Affairs of Indonesia, pages 13-14.

13 Go further in Muhammad Yusuf Musa, 1963, Falsafah alAkhlaq fi al-Islam wa Sillatuha bi al-Igriqiyyah, Ed. II, Cairo: Mu'assasah al-Khanji, page 144; Salah al-Din alSaljuqi, Asar al-Imam Al-Ghazali fi al-Akhlaq, in Mahrajan, Op.Cit., pages 79-82.

14 Al-Ghazali, Mazan al- 'Amal...loc.cit. Vol. II, pages 357359. 
Iradi (initiative action), such as breathing; and Fi'il Ikhtiari (alternative action) such as writing. Karl Bath explained a few things about view of masyi'ah (will) in widely or independence, which is cited by lan G. Barbour: 159

"God is different transedence with the others and cannot be known unless with self-disclosure. Religious beliefs entirely depends on God will, not on human invention such as science. Scientists has a freedom to do their activity without theology involvement and vice versa. Since both method and issue is different, science develop from observation and human logic, while theology is based on apocalypse."

Action [1] and [2] occur with idtirari (compulsive/ deterministic). According to Ghazali, iradah (motive) engages with the knowledge based on our suitability. This decision is often taken by mind spontaneously/reflectively, such as a condition when we close our eyes because there is a knife appointed to us, so that it generates iradah with knowledge. Moreover, by particular thought, it can be distingushed that kindness is a form of action. In this part, there is the specific iradah known as ikhtiar. Hence, ikhtiar is a formulation about specific iradah which appears with mind direction and in order to catch the point based on the idea or senses. Because of the movement forced by qudrah, qudrah forced by iradah, and iradah forced by knowledge (mind decision) based on imagine input and senses, all of them forced unconciously. Moreover, someone 'forced' means that all of those stages come from anyone else, and 'berikhtiar' (attempting).

Happiness is a reflection of conformity and harmony between natural characteristics and the purposes until it achieved. If the form of happiness must be related to the priority and consistency, so it is impossible to realize the happiness, except if there is any mediator 'causes' to the entire natural reality which comprehend the foundation of harmony and

159 Marsudi Iman, "Tipologi Hubungan Sains dan Agama dalam perspektif lan G. Barbour”, Jurnal Afkaruna, Vol. 7 No. 1, January-June 2011, Bantul: Faculty of Islamic Studies Universitas Muhammadiyah Yogyakarta, page 44. unity between happiness and priority. Thus, real (absolute) kindness becomes the highest mediator to realize high relative kindness, it is the highest absolute kidness which creates flawless nature.

In this context, the moral argument does not only define God existence but also defines God characteristics, such as the Creator, the Wise, the Will Power and the One who rules earth and heaven. This type of argument must be leaned on fitrah argument or a prioris references in which the prophets sent after the argumentation of God flawless characteristic existence, or based on one arguments, such as imkam, wujub, also movement arguments. ${ }^{20}$

Hence, morality argument has equality of validity with the previous arguments (imkam, wujub, hudus, also movement) and it is considered as the new argument. If morality argument does not based on the previous argument mentioned before, it does not have validity as an argument to define God existence. Therefore, if morality argument is considered to have complete base, it is still categorized as practice philosophy/mind not as theoritical philosophy. It cannot be used as existence evidence. Yet, it does not mean that 'priority' from mind practice ('amaliah) is produced by knowledge about morality which entirely shows God existence. In the other side, the importance of mind practice means someone defines the necessity (qualification) using 'amal (practice) or morality. Then someone leans their belief to morality (akhlak) or 'amal (practice), so their belief will be based on the universal mind practice needs.

Morality concept in prophetic paradigm is based on the concept in which the moral values is the from of affirmation of imaginative world reflected in the cognitive imagination and can be printed in the fantasy or sensitive imagination on the level in which the viewers can actually see them in their senses. Hence, the formulation of morality values in the prophetic paradigm combines the practice and theoritical mind skill. 
Prophetic Paradigm Critics Towards Morality Rational Paradigm Ethics/Value Based on H.L.A Hart Concept

According to Ghazali, knowledge must corresponds to object reality. Therefore, in formulating the prophetic paradigm moral values, there is a combination between the reality on the society and apocalypse values which is ma'lum (known), as a result between thought (rational) and dzikir (trancendental).

\section{Conclusion}

According to the conducted study, it can be concluded that: H.LA Hart's opinion is based on assumptions of basic epistemology, it comprehends primary rules; and secondary rules; meanwhile value/ethics includes: ethics epistemology, in terms of autonomous, individual, prosedural and relative. While phropetic paradigm is based on epistemology assumptions, that is relative morality which is composed of absolute invention and will reality; and morality norm which is supposed reality (sollen) which is created on authorieties will through representative, with epistomology value/ethics in sort of the combination of society reality and apocalypse values.

\section{Suggestion}

Hart believed that human has limited good will to others. Event though morality argument is in particular formulation, it should be noted that human specificially has responsibility and shame on their worst action which cannot be avoided. This proves the inevitability of God existence as given reponsibility source.

Rational paradigm strongly believes that the proposition of moral argument related to mind practice not to the theroritical mind, so there is no morality conclusion which believes theoritical statement as a valid morality sources. Meanwhile in prophetic paradigm, it has a strong correlation because morality values as affirmation of imaginative world are reflected in cognitive imagination and then recorded in sensitive imagination, or fantasy in a level where someone really see them in their senses.
As practical knowledge, in prophetic paradigm, morality uses truth parameter in logical principles, ijma', also Quran and hadits which have certain position. Ijma is an ijtihad done by the the experts. "the experts' in Gazhali's perspective has to meet moral and professional qualifications in public.

\section{References}

Al-Attas, Syed Muhammad Naquib. 1995. Islam dan Filsafat Sains. translated by Saiful Muzani. Bandung: Mizan;

Al-Ghazali. $1409 \mathrm{H} / 1988$. Mi'yar al-‘llm, edition of Sulayman Dunya. Edition II. Egypt: alMa'arif;

-.---. 1963. Mazan al-Amal Edition of Of Sulayman Dunya, Vol.I and II, Edition II. Egypt: dar al-Ma'arif;

Azizah, Noor. "Urgensi Filsafat Ilmu Bagi Ilmu Hukum”. Jurnal Al 'Ulum. Vol. 51 No. 1. January 2012. Gorontalo: IAIN Sultan Amai;

Dwisvimiar, Inge. "Keadilan Dalam Perspektif Filsafat Ilmu Hukum". Jurnal Dinamika Hukum. Vol. 11 No. 3 September 2011. Purwokerto: Faculty of Law of Universitas Jenderal Soedirman;

Groudine, Candace J."Authority: H. L. A. Hart and the Problem with Legal Positivism". The Journal of Libertarian Studies. Vol. IV. No. 3. Isumrnrr 1980. New York: Department of Philosophy of Columbia University;

Iman, Marsudi. "Tipologi Hubungan Sains dan Agama dalam perspektif lan G. Barbour". Jurnal Afkaruna. Vol. 7 Number 1. January-June 2011. Bantul: Faculty of Islamic Studies of Universitas Muhammadiyah Yogyakarta;

Iswanto, Agus. "Relasi manusia Dengan Lingkungan dalam Al-Quran: Upaya Membangun Eco-Theology”. Jurnal Suhuf. Vol. 6 No. 1. 2013. Jakarta: Agency of Research, Development, Education and Training of Ministry of Religious Affairs of Indonesia;

Luthan, Salman. "Dialektika Hukum dan Moral dalam Perspektif Filsafat Hukum”. Jurnal Hukum IUS QUIA IUSTUM. Vol. 19 No. 4. October 2012. Yogyakarta: Faculty of Law of Universitas Islam Indonesia;

Meuwissen, D.H.M. "Filsafat Hukum". Jurnal Hukum Pro Justitia. Year XII No. 1. July 1994. Bandung: Faculty of Law of Universitas Parahyangan; 
. "Ilmu Hukum". Jurnal Hukum Pro Justitia. Year XII No. 1. July 1994. Bandung: Faculty of Law of Universitas Parahyangan.

.Pengembangan Hukum". Jurnal Hukum Pro Justitia. Year XII Number 1. January 1994. Bandung: Faculty of Law of Universitas Parahyangan;

. "Teori Hukum". Jurnal Hukum Pro Justitia. Year XII Number 1. April 1994. Bandung: Faculty of Law of Universitas Parah-yangan;

Musa, Muhammad Yusuf. 1963. Falsafah alAkhlaq fi al-Islam wa Sillatuha bi al-Igriqiyyah. Edition II. Kairo: Mu'assasah alKhanji;

Poloma, Margaret M. 2000. Sosiologi Kontemporer. Translated from Contemporary Sociology Theory by Yasogama team. Jakarta: PT. RajaGrafindo Persada;

Putera, Heddy Shri Ahimsa. "Paradigma Profetik: Mungkinkah? Perlukah?". Makalah. Delivered in "Saresehan Profetik 2011" held by Master Program of Universitas Ga- djah Mada in Yogyakarta. February $10^{\text {th }}$ 2011;

Rahardjo, Turnomo. "Landasan Filosofis Penelitian Komunikasi". Jurnal Semai Komunikasi. Vol. II No. 1. December 2011. Semarang: Communication Science Academy Semarang;

Raharjo, Agus. "Hukum dan Dilema Pencitraannya: Transisi Paradigmatis Ilmu Hukum dalam Teori dan Praktek". Jurnal Hukum Pro Justitia. Vol. 24. No. 1. January 2006. Bandung: Faculty of Law of Universitas Parahyangan;

"Membangun Hukum yang Humanis". Jurnal Hukum Pro Justitia. Year XX No. 2. April 2002. Bandung: Faculty of Law of Universitas Parahyangan;

Satjipto Rahardjo. "Hukum Progresif: Hukum yang Membebaskan". Jurnal Hukum Progresif. Vol. 1 No. 1. April 2005. Semarang: Doctoral Programs of Law Science Universitas Diponegoro;

Summers, Robert. "Professor H.L.A. Hart Concept of Law". Duke Law Journal. Vol. 1963 Number 629. Durham: Duke University School of Law. 